\title{
Effect of quantity and source of rumen nitrogen on the efficiency of microbial protein synthesis in steers consuming tropical forage
}

\author{
M. K. Bowen ${ }^{\mathrm{A}, \mathrm{B}, \mathrm{D}}$, D. P. Poppi ${ }^{\mathrm{A}}$ and S. R. McLennan ${ }^{\mathrm{C}}$

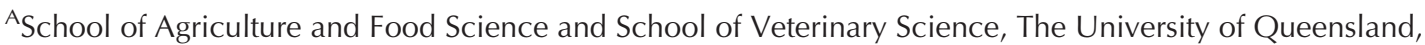 \\ Gatton, Qld 4343, Australia. \\ ${ }^{B}$ Present address: Department of Agriculture and Fisheries, Rockhampton, Qld 4701, Australia. \\ ${ }^{\mathrm{C}}$ The University of Queensland, Centre for Animal Science, Queensland Alliance for Agriculture \\ and Food Innovation, Brisbane Qld 4105, Australia. \\ DCorresponding author. Email: maree.bowen@daf.qld.gov.au
}

\begin{abstract}
Low values for the efficiency of microbial protein synthesis (EMPS) in cattle consuming tropical forages are related to low rumen degradable crude protein (RDP) intakes. This study examined the effect on the EMPS of the quantity and source of nitrogen $(\mathrm{N})$ supplied to the rumen of eight entire and four rumen-fistulated Brahman steers consuming mature tropical grass hay $(57.3 \mathrm{~g}$ crude protein $/ \mathrm{kg} \mathrm{DM})$. Four treatment diets were fed in a Latin square design and included a basal diet of mature pangola grass (Digitaria eriantha) hay (control) and hay plus supplements estimated to provide $150 \mathrm{~g} \mathrm{RDP} / \mathrm{kg}$ digestible organic matter intake (DOMI), as urea or casein, or $300 \mathrm{~g} \mathrm{RDP} / \mathrm{kg}$ DOMI as casein. The EMPS was only increased $(P<0.05)$ above that for the control diet (167 vs $123 \mathrm{~g}$ microbial crude protein $(\mathrm{MCP}) / \mathrm{kg}$ DOMI) when RDP was provided at the highest rate of $293 \mathrm{~g} / \mathrm{kg}$ DOMI. This increase was also associated with an $\sim 4$-fold increase in the concentration of $\mathrm{NH}_{3}-\mathrm{N}$ ( $277 \mathrm{vs} 73 \mathrm{mg} / \mathrm{L}$ ) and of branched-chain volatile fatty acids ( $44 \mathrm{vs} 10 \mathrm{mmol} / \mathrm{mol}$ of total volatile fatty acids) in rumen fluid of the steers. However, the source of rumen degradable N (urea or casein) had no effect on the EMPS (109-115 g MCP/kg DOMI) when supplied at $\sim 150 \mathrm{~g} \mathrm{RDP} / \mathrm{kg}$ DOMI. There was no effect of treatment on in vivo neutral detergent fibre digestibility $(599 \mathrm{~g} / \mathrm{kg} \mathrm{DM})$ or the rate $(0.037 / \mathrm{h})$ or extent (potential degradable fraction: $636 \mathrm{~g} / \mathrm{kg} \mathrm{OM}$ ) of in sacco disappearance of pangola grass hay. In addition, rumen particle dilution rate was unaffected by treatment $(0.022 / \mathrm{h})$ and rumen fluid dilution rate, although showing some treatment differences $(0.048-0.062 / \mathrm{h})$, was poorly correlated with EMPS. It was concluded that only high amounts of RDP supply to the rumen, in the form of true protein, resulted in increased EMPS whereas at the lower intakes of RDP formulated to achieve EMPS in the range suggested in the feeding standards (130-170 $\mathrm{g}$ $\mathrm{MCP} / \mathrm{kg} \mathrm{DOMI}$ ) there was no difference in providing the RDP as non-protein $\mathrm{N}$ or degradable-protein.
\end{abstract}

Additional keywords: nitrogen source, urinary purine derivatives.

Received 21 October 2015, accepted 20 October 2015, published online 2 December 2016

\section{Introduction}

Low efficiencies of microbial protein synthesis (EMPS) are routinely reported for both penned and grazing cattle consuming tropical grass forages (Panjaitan et al. 2010, 2015; Tuyen et al. 2015; Bowen et al. 2016). These values are generally much lower than the range of EMPS values proposed in the feeding standards, viz. 130-170 g microbial crude protein (MCP)/kg digestible organic matter intake (DOMI; AFRC 1993; NRDR 2007), and are associated with a low degradable protein concentration in the rumen (RDP). Temperate species of grass and legume are generally associated with EMPS at the higher end of the feeding standards range, i.e. $\geq 170 \mathrm{~g} \mathrm{MCP} / \mathrm{kg}$ DOMI, and are often associated with very high RDP concentrations (e.g. Beever et al. 1986; Bowen et al. 2016). The theoretical maximum EMPS, based on the stoichiometry of ruminal fermentation, is $\sim 225 \mathrm{~g} \mathrm{MCP} / \mathrm{kg}$ DOMI (Corbett et al. 1982; Corbett 1987; NRDR 2007). Some reported values for temperate pastures approach this maximum, for example, $209 \mathrm{~g}$ $\mathrm{MCP} / \mathrm{kg}$ DOMI measured for cattle grazing ryegrass pasture (Bowen et al. 2016), and are certainly at the high end of the feeding standards range ( $170 \mathrm{~g} \mathrm{MCP} / \mathrm{kg} \mathrm{DOMI})$, which is rarely reached with tropical forages (Detmann et al. 2014).

Increasing dietary RDP supply is thus used as a strategy to increase the EMPS of cattle grazing tropical pastures (Poppi and McLennan 2010). The importance of increasing EMPS is that MCP usually provides the majority of the total protein supply to ruminants grazing tropical pastures (NRDR 2007) so that increases in EMPS should lead to increased liveweight gain of cattle grazing these pastures through increases in total metabolisable protein supply (Poppi and McLennan 1995; 
Poppi et al. 1997). In addition to the quantity of RDP supplied, the source of RDP, i.e. whether in the form of non-protein nitrogen (NPN) or derived from true protein, may be important with studies showing responses in microbial protein yield to higher volatile fatty acids (VFA), amino acids or protein compared with NPN (e.g. Hume 1970a, 1970b; Amos and Evans 1976; Ben-Ghedalia et al. 1978).

The objective of this experiment was to determine the effect of quantity and source of rumen $\mathrm{N}$, i.e. whether in the form of NPN or derived from true protein, on EMPS in steers fed low-protein, tropical grass. The approach was to investigate strategies to increase the EMPS, in cattle consuming tropical grasses, to the levels reported for ruminants consuming temperate forages.

\section{Materials and methods}

This experiment was conducted at the University of Queensland's Mt Cotton Research Farm, Queensland, Australia, and was reviewed and approved by the University of Queensland Animal Ethics Committee.

\section{Animals, experimental design and procedures}

Eight Brahman ( $>75 \%$ Bos indicus) steers (374 \pm 8.8 (s.e.) $\mathrm{kg})$, (hereafter, intact steers) and four Brahman ( $>75 \%$ B. indicus) rumen-fistulated steers $(568 \pm 28.4 \mathrm{~kg})$, (hereafter, RF steers), were used in separate Latin square designs to examine the effect of four treatment diets. The eight intact steers were treated with moxidectin (Cydectin, Fort Dodge Australia Pty Ltd, Sydney, NSW, Australia) at the commencement of the preliminary feeding period to control internal and external parasites. The RF steers were treated with flumethrin (Bayticol, Bayer Australia Ltd, Pymble, NSW, Australia) when required during the experiment to control buffalo fly.

The following dietary treatments were applied with both the intact and RF steers: (1) control diet of low-quality, pangola grass (Digitaria eriantha) hay (C); (2) hay + urea and ammonium sulfate, to achieve $150 \mathrm{~g}$ RDP/kg DOMI, (U); (3) hay + casein, to achieve $150 \mathrm{~g} \mathrm{RDP} / \mathrm{kg}$ DOMI (LoCAS); and (4) hay + casein, to achieve $300 \mathrm{~g}$ RDP/kg DOMI (HiCAS). With all treatments, including the control, water was added to the hay at the rate of $300 \mathrm{~g} / \mathrm{kg}$ (w/w, air-dry basis) and mixed well with the hay. For the $\mathrm{U}$ treatment, urea and ammonium sulfate (to achieve a $\mathrm{N}$ : sulfur (S) ratio in the supplement of $14.3: 1$ ) were dissolved in the water before it being sprayed on to the hay. The LoCAS and HiCAS treatments involved sifting casein (sodium caseinate, Murray Goulburn Co-op. Co. Ltd, Southbank, Vic., Australia) on to the hay after water application, followed by thorough mixing. A mineral block (Olsson's Go-Block, Olsson Industries Pty Ltd, Yennora, NSW, Australia) containing macro- and trace minerals, but no N, was made available to all intact and RF steers during the first 9 days of each preliminary feeding period.

For the intact steers, a 14-day preliminary feeding period in individual pens preceded a 7-day measurement period in metabolism crates for each of the four experimental periods. The steers were fed ad libitum during preliminary feeding periods and then restricted to $90 \%$ of ad libitum during the collection periods. All diets were fed once daily at $\sim 0800$ hours. For each steer, feed intake was recorded over the 7-day sampling period and total faecal and urine outputs were collected daily. Urine was collected into bins containing a sufficient quantity of $20 \%(\mathrm{v} / \mathrm{v})$ sulfuric acid solution so that the final $\mathrm{pH}$ of urine was kept below 3. Urine was weighed and a 5\% daily subsample was kept and bulked for each steer over the measurement period. These samples were stored frozen $\left(-20^{\circ} \mathrm{C}\right)$ and later thawed, mixed thoroughly, subsampled, and diluted 1 in $10(\mathrm{v} / \mathrm{v})$ with $0.1 \mathrm{M}$ ammonium phosphate $\left(\mathrm{NH}_{4} \mathrm{H}_{2} \mathrm{PO}_{4}\right)$ buffer. The buffered samples were frozen before analysis for purine derivative concentration.

The RF steers were held in individual pens for the duration of each of the four experimental periods, which included a 14-day preliminary feeding period followed by a 6-day sampling period. The feeding regime and measurements of daily feed intake were the same as for the intact steers. Rumen fluid samples were collected from each of the steers at 4-hourly intervals over $24 \mathrm{~h}(0,4,8,12,16,20,24 \mathrm{~h}$ post-feeding) from Day 1 of each sampling period. A sampling probe was used to collect strained rumen fluid from at least three different sites in the rumen of each steer. Rumen fluid $\mathrm{pH}$ was determined immediately after sample collection with a portable $\mathrm{pH}$ meter and subsamples were taken for VFA and ammonia- $\mathrm{N}\left(\mathrm{NH}_{3}-\mathrm{N}\right)$ analyses for all except the 24-h sampling time. Only one representative bulk subsample of the six sampling times for each steer was analysed for VFA concentration. On Day 1 of each sampling period, concentrated CrEDTA solution (2.7 g Cr/steer) and Yb-marked hay ( $1 \mathrm{~g} \mathrm{Yb} /$ steer) were dosed into the rumen through the cannula immediately before daily feeding. The CrEDTA solution was injected into at least four different sites in the rumen and washed in with $200 \mathrm{~mL}$ of water. Three packets, each containing $10 \mathrm{~g}$ of Yb-marked hay (oven-dried, 3-mm ground pangola grass hay) were dosed into three different sites in the rumen, one being the posterior ventral sac. Rumen fluid and digesta samples were taken at 4,8 , $12,16,20,32$ and $48 \mathrm{~h}$ after dosing for analysis of $\mathrm{Cr}$ in rumen fluid and $\mathrm{Yb}$ in digesta. Commencing on Day 3 of the sampling period, a representative portion of the basal diet of pangola grass hay (3-mm ground) was incubated in sacco in polyester bags (Allied Filter Fabrics; monofilament polyester, $24 \times 10 \mathrm{~cm}$ outer dimension, pore size $45 \mu \mathrm{m}$ ). The samples were incubated in duplicate in each steer from $\sim 0800$ hours for each of eight incubation times $(3,6,9,12,24,48,72$ and $96 \mathrm{~h})$ and processed, as described previously by Bowen et al. (2008), for determination of organic matter (OM) disappearance.

After completion of the final experimental period, three of the four RF steers $(564 \pm 37.6 \mathrm{~kg})$ were used in an in sacco study to determine the RDP content of the pangola grass hay. The steers were fed twice daily (0730 hours and 1530 hours, in equal portions) a standard diet consisting of a mixture of lucerne (Medicago sativa) and pangola grass hays $(3: 5 \mathrm{w} / \mathrm{w}$, as fed), at $90 \%$ of pre-determined ad libitum intake, plus $1 \mathrm{~kg}$ of cottonseed meal. After a 6-day preliminary feeding period the polyester bags containing the hay ( $3 \mathrm{~mm}$ ground) were incubated in duplicate in each steer from 0800 hours for each of five incubation times $(5,8,11,14$ and $16 \mathrm{~h})$. The effective protein degradability of the pangola grass hay was determined by measuring the rate of disappearance of neutral detergent insoluble nitrogen (NDIN), after subtraction of the acid detergent insoluble nitrogen (ADIN) component, in the incubated samples as described in Bowen et al. (2008). 


\section{Analytical procedures}

The DM content of samples was determined by drying to a constant weight in a forced draught oven at $65^{\circ} \mathrm{C}$. Samples were milled to $<1 \mathrm{~mm}$ before chemical analysis. The ash content was determined by heating dry samples in an electric muffle furnace (Thermogravimetric analyser TGA-601, LECO Corporation: St Joseph, MI, USA) at $610^{\circ} \mathrm{C}$ to constant weight under an atmosphere of oxygen. Feed samples were analysed for total-N concentration by a combustion method (Sweeney 1989) using an Elementar RapidN analyser (Elementar Analysensysteme GmbH, Hanau, Germany). Feed and faecal samples were analysed for ash-free neutral detergent fibre (NDF) and ash-free acid detergent fibre (ADF) using the Fibretec 2021 Fibrecap system (Foss Tecator 2002a, 2002b). The NDIN and ADIN concentrations were determined on the residues of rumenincubated hay samples by analysis for fibre and then N. Acidified and buffered urine samples were thawed, filtered through a $0.2-\mu \mathrm{m}$ Alltech cellulose nitrate or acetate membrane filter followed by a C18, 300-mg filter, and analysed for purine derivative concentration using a high-performance liquid chromatograph (Waters model $600 \mathrm{E}$, USA) according to the method outlined by Balcells et al. (1992). The concentrations of VFA present in rumen fluid samples were determined by gas chromatography using a polar capillary column (DB-FFAP), after initial protein precipitation with metaphosphoric acid. Prior to determination of rumen $\mathrm{NH}_{3}-\mathrm{N}$ concentration, rumen fluid was shaken and then centrifuged ( $2600 \mathrm{~g}$ for $12 \mathrm{~min}$ ) to obtain a clear supernatant. After a reaction, which converts ammonia to form an indophenol dye (Bolleter et al. 1961) spectrophotometric determination was conducted on an Olympus AU400 clinical analyser. Rumen fluid samples were centrifuged ( $2600 \mathrm{~g}$ for $10 \mathrm{~min}$ ) before analysis for Cr using a Varian 220FS atomic absorption spectrometer with an air acetylene flame. Digesta samples were analysed for $\mathrm{Yb}$ using an inductively coupled plasma atomic emission spectrometer. The samples were first prepared for analysis by digestion using a mixture of 5 nitric acid : 1 perchloric acid as in de Vega and Poppi (1997).

\section{Calculations}

The protein degradability of the pangola grass hay, determined from the in sacco digestion followed by determination of NDIN and ADIN content, was used to estimate RDP contribution from the hay portion of the treatment diets, as described in Bowen et al. (2008). Urea and casein were assumed to be $100 \%$ degraded in the rumen. The flow of MCP to the intestines of steers was calculated using the equations proposed by Chen and Gomes (1995). These calculations were made using the value for endogenous purine derivative excretion determined for highcontent (>75\%) B. indicus cattle by Bowen et al. (2006), i.e. $190 \mu \mathrm{mol} / \mathrm{kg} \mathrm{W}^{0.75}$.day. The fractional outflow rate (FOR) of $\mathrm{Cr}$ and $\mathrm{Yb}$ in rumen fluid and digesta, respectively, were determined by regressing the natural $\log (\mathrm{ln})$ of $\mathrm{Cr}$ and $\mathrm{Yb}$ concentrations against time, with the rate constant, $k$, determined as the slope of the regression so that FOR $(/ \mathrm{h})=-k$. The rumen fluid volume and the digesta DM weight were calculated as follows: rumen fluid volume $(\mathrm{L})$ or digesta DM weight $(\mathrm{kg})=$ marker injected $(\mathrm{mg}) / A_{0}$ ( $\mathrm{mg} / \mathrm{L}$ or $\mathrm{mg} / \mathrm{kg} \mathrm{DM})$, where $A_{0}$ is the concentration of marker at time 0 hours. The disappearance of pangola grass hay $\mathrm{OM}(\mathrm{g} / \mathrm{kg})$ from polyester bags was plotted against time, using the statistical package Genstat for Windows (6th edition; Genstat Committee 2000) and the model described by McDonald (1981), as detailed in Bowen et al. (2008).

\section{Statistical analyses}

Differences between treatment means were tested by ANOVA. Pair-wise differences between means were tested using a protected least significance difference procedure $(P=0.05)$. Poor relationships were obtained in some cases for the simple linear regression of the $\ln$ of $\mathrm{Yb}$ concentration against time. Thus, the individual regressions were tested to determine whether the slope was significantly different to 0 , and those that were not were excluded from the calculation of particle FOR. Four out of the 16 regressions were excluded on this basis. In order to test for treatment effects on in sacco OM disappearance parameters, individual exponential curves were fitted to the data for each steer in each period. The form of the exponential used was $Y=S+Q R^{t}$, where $Y$ is the OM disappearance $(\mathrm{g} / \mathrm{kg})$, $S$ is the constant parameter, $Q$ is the linear parameter, $R$ is the curvature parameter, and $t$ represents incubation time (h). The coefficients $(S, Q$ and $R$ ) were extracted from each dataset and separately subjected to a Latin square ANOVA. There were no significant differences between the coefficients, and thus a pooled estimate of the curve was used. The mean curve was re-parameterised so that $Y_{1}=A$ up to time $t_{0}$, and $Y_{2}=a+$ $b\left(1-\mathrm{e}^{-c t}\right)$, from time $t_{0}$ onwards. In these equations, $A$ is the measured washing loss from non-incubated polyester bags $(\mathrm{g} / \mathrm{kg})$, $a$ is the rapidly degraded fraction $(\mathrm{g} / \mathrm{kg}), b$ is the more slowly degraded fraction $(\mathrm{g} / \mathrm{kg}), a+b$ represents the potential degradable fraction $(\mathrm{g} / \mathrm{kg}), c$ is the degradation rate $(/ \mathrm{h})$ of $b$ and $t_{0}$ is the lag time (h) before the commencement of degradation of $b$, calculated from the fitted equation as the value of $t$ when $Y=A$. All data were analysed using the statistical package Genstat for Windows (6th edition; Genstat Committee 2000).

\section{Results}

The nutrient composition of pangola grass hay confirmed it was of low quality: OM, $936 \mathrm{~g} / \mathrm{kg}$ DM; crude protein (CP), $57.3 \mathrm{~g} / \mathrm{kg}$ DM; effective degradability of the protein fraction, $860 \mathrm{~g} / \mathrm{kg} \mathrm{CP}$; NDF, 697 g/kg DM; and ADF, 401 g/kg DM. Casein OM content was $961 \mathrm{~g} / \mathrm{kg} \mathrm{DM}$ and CP content was $950 \mathrm{~g} / \mathrm{kg} \mathrm{DM}$. The measured ratios of RDP/DOMI in the dietary intake of steers were very close to those intended of 150 (U and LoCAS) and $300 \mathrm{~g} / \mathrm{kg}$ (HiCAS; Table 1). Protein consumption by steers (both $\mathrm{CP}$ and RDP) relative to DOMI was not different between $\mathrm{U}$ and LoCAS treatments $(P>0.05)$, but these were greater $(P<0.05)$ than that for the $\mathrm{C}$ treatment and lower $(P<0.05)$ than for the HiCAS treatment. The estimated flow of MCP from the rumen of steers and EMPS were increased with feeding of casein at the highest rate (HiCAS) relative to all other treatments $(P<0.05$; Table 1). However, the U and LoCAS treatments did not increase MCP flow or EMPS in steers relative to C. NDF digestibility was not affected by treatment, with a mean value of $599 \pm 5.4 \mathrm{~g} / \mathrm{kg}$ DM across all treatments (Table 1). However, OM digestibility and DOMI values for HiCAS steers were greater than for all other treatments $(P<0.05)$. Inclusion of casein at the lower rate (LoCAS) was associated with increased OM digestibility relative 
Table 1. Effect of quantity and source of rumen nitrogen on the intake of crude protein (CP) and rumen-degradable protein (RDP), relative to that of digestible organic matter intake (DOMI), and on the flow of microbial crude protein (MCP) from the rumen, the efficiency of MCP synthesis in the rumen (EMPS), digestibility of organic matter (OMD) and neutral detergent fibre (NDFD), and on DOMI for intact (non-fistulated) steers

Treatment descriptions are given in the text. Values with rows followed by different letters are significantly different at $P=0.05$. LW, liveweight; s.e., standard error; $P$, probability for test of significant difference between treatments

\begin{tabular}{lcccccc}
\hline & \multicolumn{7}{c}{ Treatment } & s.e. & $P$ \\
& $\mathrm{C}$ & $\mathrm{U}$ & LoCAS & HiCAS & & \\
\hline Intake & & & & & 2.2 & $<0.001$ \\
CP (g/kg DOMI) & $127 \mathrm{a}$ & $167 \mathrm{~b}$ & $169 \mathrm{~b}$ & $307 \mathrm{c}$ & 2.1 & $<0.001$ \\
RDP (g/kg DOMI) & $109 \mathrm{a}$ & $150 \mathrm{~b}$ & $153 \mathrm{~b}$ & $293 \mathrm{c}$ & 44.7 & $<0.001$ \\
MCP flow (g/day) & $288 \mathrm{a}$ & $298 \mathrm{a}$ & $315 \mathrm{a}$ & $570 \mathrm{~b}$ & 14.2 & 0.04 \\
EMPS (g MCP/kg DOMI) & $123 \mathrm{a}$ & $115 \mathrm{a}$ & $109 \mathrm{a}$ & $167 \mathrm{~b}$ & 5.3 & $<0.001$ \\
OMD (g/kg DM) & $498 \mathrm{a}$ & $512 \mathrm{ab}$ & $525 \mathrm{~b}$ & $563 \mathrm{c}$ & 5.4 & 0.48 \\
NDFD $(\mathrm{g} / \mathrm{kg} \mathrm{DM})$ & 592 & 603 & 603 & 599 & 0.020 & $<0.001$ \\
DOMI $(\mathrm{kg} / 100 \mathrm{~kg} \mathrm{LW})^{\mathrm{A}}$ & $0.62 \mathrm{a}$ & $0.67 \mathrm{a}$ & $0.76 \mathrm{~b}$ & $0.89 \mathrm{c}$ & &
\end{tabular}

${ }^{\mathrm{A}}$ DOMI values were determined during sampling periods when intakes were restricted to $90 \%$ of the ad libitum intakes of the preliminary period.

Table 2. Effect of quantity and source of rumen nitrogen $(\mathrm{N})$ on the concentration of ammonia- $\mathrm{N}\left(\mathrm{NH}_{3}-\mathrm{N}\right)$, the molar proportions of volatile fatty acids (VFA), and the fluid volume and digesta DM weight in the rumen, and on the fractional outflow rates (FOR) from the rumen of fluid and particulate matter, for rumen-fistulated steers

Treatment descriptions are given in the text. Values within rows followed by different letters are significantly different at $P=0.05$. BCFA, branched-chain volatile fatty acids, being the sum of iso-butyrate and iso-valerate; s.e., standard error; $P$, probability for test of significant difference

\begin{tabular}{|c|c|c|c|c|c|c|}
\hline & \multicolumn{4}{|c|}{ Treatment } & \multirow[t]{2}{*}{ s.e. } & \multirow[t]{2}{*}{$P$} \\
\hline & $\mathrm{C}$ & $\mathrm{U}$ & LoCAS & HiCAS & & \\
\hline Rumen $\mathrm{NH}_{3}-\mathrm{N}$ concentration $(\mathrm{mg} / \mathrm{L})$ & $73.4 \mathrm{a}$ & $134.5 b$ & $121.0 \mathrm{~b}$ & $277.0 \mathrm{c}$ & 8.99 & $<0.001$ \\
\hline \multicolumn{7}{|l|}{ VFA molar proportion $(\mathrm{mmol} / \mathrm{mol})$} \\
\hline Acetate & $764 b$ & $721 \mathrm{ab}$ & $719 \mathrm{ab}$ & $689 \mathrm{a}$ & 14.0 & 0.05 \\
\hline Propionate & 141 & 171 & 171 & 172 & 11.8 & 0.49 \\
\hline Butyrate & 73 & 92 & 87 & 82 & 4.5 & 0.71 \\
\hline Valerate & 12 & 5.7 & 6.5 & 12 & 4.5 & 0.60 \\
\hline BCFA & $10 \mathrm{a}$ & $10 \mathrm{a}$ & $16 \mathrm{~b}$ & $44 \mathrm{c}$ & 1.6 & $<0.001$ \\
\hline Fluid FOR (/h) & $0.048 \mathrm{a}$ & $0.054 \mathrm{ab}$ & $0.060 \mathrm{bc}$ & $0.062 \mathrm{c}$ & 0.0019 & 0.01 \\
\hline Particle FOR (/h) & 0.020 & 0.021 & 0.017 & 0.030 & 0.0039 & 0.26 \\
\hline Rumen fluid volume (L) & 57.0 & 52.3 & 57.4 & 52.6 & 3.58 & 0.64 \\
\hline Rumen digesta DM weight $(\mathrm{kg})$ & 11.0 & 9.8 & 14.1 & 9.9 & 1.25 & 0.22 \\
\hline
\end{tabular}

to the $\mathrm{C}$ treatment and increased DOMI relative to the $\mathrm{C}$ and $\mathrm{U}$ treatments, where differences were not significant between the $\mathrm{C}$ and $U$ steers for these attributes. The disappearance of pangola hay OM in sacco in RF steers was unaffected by treatment (S coefficient, $P=0.58$; Q coefficient, $P=0.64$; R coefficient, $P=0.51)$. The OM disappearance coefficients, determined from pooled estimates of the curve representing the four treatment diets, were: $a, 140 \pm 5.0 \mathrm{~g} / \mathrm{kg} \mathrm{OM} ; b, 496 \pm 5.1 \mathrm{~g} / \mathrm{kg} \mathrm{OM} ; a+b$, $636 \mathrm{~g} / \mathrm{kg} \mathrm{OM} ; c, 0.037 \pm 0.0014 / \mathrm{h}$; where the residual standard deviation of the fitted equation $=4.6$.

The concentration of $\mathrm{NH}_{3}-\mathrm{N}$ in the rumen of $\mathrm{RF}$ steers increased with the addition of RDP in the form of urea or casein at the low rate $(P<0.05)$, where these treatments were not different, and then increased further when the higher rate of casein was fed $(P<0.05$; Table 2$)$. Steers consuming the $\mathrm{C}$ diet maintained a low $\mathrm{NH}_{3}-\mathrm{N}$ concentration $(<100 \mathrm{mg} / \mathrm{L})$ throughout the 20-h sampling period, with the peak concentration (96.3 mg/L) occurring just before feeding. By contrast, $\mathrm{NH}_{3}-\mathrm{N}$ concentration for the other treatment groups peaked at $4 \mathrm{~h}$ ( $190 \mathrm{mg} / \mathrm{L}$; U and LoCAS) or $8 \mathrm{~h}(338 \mathrm{mg} / \mathrm{L}$; HiCAS) after feeding. The average $\mathrm{pH}$ in rumen fluid over the $24 \mathrm{~h}$ after feeding was not different between treatment diets $(P=0.09)$, averaging $6.8 \pm 0.03$. The total molar concentration of VFA in the rumen of RF steers was also unaffected by treatment $(P=0.99)$, averaging $27.6 \pm 2.04 \mathrm{mM}$. The LoCAS treatment was associated with an increase in the molar proportion of branched-chain volatile fatty acids (BCFA) relative to the $\mathrm{C}$ and $\mathrm{U}$ treatments $(P<0.05)$, which were not different from one another (Table 2), whereas the HiCAS treatment resulted in a further increase relative to the LoCAS treatment $(P<0.05)$, with the molar proportion four times greater than for the $\mathrm{C}$ and $\mathrm{U}$ treatments. The trend for the acetate molar proportions was in the reverse order, but with differences only between HiCAS and C. The FOR of fluid from the rumen of RF steers was lowest on $\mathrm{C}$ and $\mathrm{U}$ treatments, but with no difference between $U$ and LoCAS (Table 2). Furthermore, HiCAS and LoCAS treatment groups were not significantly 
different in fluid FOR. There was no significant effect of treatment on FOR of particulate matter from the rumen or on rumen fluid volume or digesta DM weight.

\section{Discussion}

Our experiment demonstrated that the EMPS in steers consuming a low-quality tropical grass hay was only increased to the higher end of the range given in the feeding standards $(170 \mathrm{~g} \mathrm{MCP} / \mathrm{kg}$ DOMI; AFRC 1993; NRDR 2007) when RDP was provided at the very high concentration of $293 \mathrm{~g} / \mathrm{kg}$ DOMI. By contrast, RDP intake at the lower rate of $150 \mathrm{~g} / \mathrm{kg}$ DOMI had no effect when provided as either NPN or true protein. These results are in contrast to those of Panjaitan et al. (2015) who found marked increases in EMPS when NPN (urea and ammonium sulfate) or a true protein supplement (Spirulina algae) were fed to steers consuming low-quality tropical grass hay, with the rate of increase being greater with the algae supplement. However, compared with our experiment, the tropical grass hay used by Panjaitan et al. (2015) had much lower RDP/DOMI, viz. 62 compared with $109 \mathrm{~g} / \mathrm{kg}$. Furthermore, the peak EMPS in steers supplemented with NPN in their study was only $92 \mathrm{~g} \mathrm{MCP} / \mathrm{kg}$ DOMI, achieved with NPN supplementation to provide $175 \mathrm{~g}$ RDP/ $\mathrm{kg}$ DOMI, and was thus well below the EMPS obtained for steers consuming even the $\mathrm{C}$ diet in our experiment (123 g MCP/ kg DOMI). In the experiment of Panjaitan et al. (2015), EMPS was only increased to the higher end of the range indicated in the feeding standards (166 g MCP/kg DOMI; AFRC 1993; NRDR 2007 ) with true protein supplementation providing $358 \mathrm{~g} \mathrm{RDP} / \mathrm{kg}$ DOMI. In our experiment, a similar EMPS of $167 \mathrm{~g} \mathrm{MCP} / \mathrm{kg}$ DOMI was achieved with true protein supplementation providing $293 \mathrm{~g} \mathrm{RDP} / \mathrm{kg}$ DOMI, or $\sim 80 \%$ of that provided by Panjaitan et al. (2015). In both experiments, very high RDP supply was associated with high EMPS. The practical significance is that increasing EMPS from the commonly quoted values for tropical forages of $<130 \mathrm{~g} \mathrm{MCP} / \mathrm{kg}$ DOMI (NRDR 2007; Valadares Filho et al. 2010); to the values at the higher end of the feeding standards' range ( $170 \mathrm{~g} / \mathrm{kg} \mathrm{MCP} / \mathrm{kg}$ DOMI) would result in significant increases in liveweight gain of $\sim 300 \mathrm{~g} /$ day (Poppi et al. 1997), although this is a very inefficient use of CP. At such high levels of RDP/DOMI required to achieve a high EMPS, there is a large loss of $\mathrm{N}$ from the rumen with resulting environmental consequences and so there are both positive and negative consequences of such an approach.

The lack of a response in EMPS to low intakes of RDP in our experiment could reflect the elevated rumen $\mathrm{NH}_{3}-\mathrm{N}$ concentration measured for steers consuming the pangola grass hay diet $(73.4 \mathrm{mg} / \mathrm{L})$, which exceeded the suggested threshold concentration of $50 \mathrm{mg} / \mathrm{L}$ proposed by Satter and Slyter (1974) for optimal MCP synthesis in the rumen. Hence, even though the RDP supply from the tropical grass hay was considered limiting for achieving the EMPS proposed in the feeding standards (i.e. RDP supply $<130 \mathrm{~g} / \mathrm{kg}$ DOMI), there was no increase in the EMPS associated with increasing rumen $\mathrm{NH}_{3}-\mathrm{N}$ concentration to $120-135 \mathrm{mg} / \mathrm{L}$, as achieved with RDP inclusion in the diet at $150 \mathrm{~g} / \mathrm{kg}$ DOMI. The rumen $\mathrm{NH}_{3}-\mathrm{N}$ concentration in steers consuming the pangola grass hay diet most likely reflects recycling of $\mathrm{N}$ in the order of $26 \mathrm{~g} \mathrm{~N} /$ day in these animals (Reynolds and Kristensen 2008). Although there was diurnal variation in rumen $\mathrm{NH}_{3}-\mathrm{N}$ concentration, it was associated with pattern of feeding over the day. The method of application of the $\mathrm{N}$ source ensured a degree of synchrony between $\mathrm{N}$ supply and fermentation of the hay substrate.

There appeared to be no advantage in providing the RDP as a true protein source instead of as NPN when offered at the lower rate of inclusion (150 g/ $\mathrm{kg}$ DOMI). In our experiment, casein would have provided to the rumen microbes a range of products of protein degradation including peptides, amino acids, ammonia, BCFA and other higher VFA such as phenyl-substituted fatty acids. The molar proportions of BCFA in rumen fluid were increased above the low values measured for the $\mathrm{C}$ and $\mathrm{U}$ diets of $10 \mathrm{mmol} / \mathrm{mol}$ by a factor of 1.6 and 4.4 for the low and high intakes of casein supplement, respectively. It has been shown that BCFA and other higher VFA are essential factors for the growth of many rumen bacterial species which ferment structural carbohydrates (Bryant and Robinson 1962; Bryant 1973) and that the growth of these bacteria in pure cultures can be stimulated by provision of peptides and amino acids cf. NPN (e.g. Cruz Soto et al. 1994). Furthermore, in vivo studies with sheep demonstrated that EMPS could be increased by substituting either casein or zein for BCFA and 50\% of urea-N (Hume 1970b). However, Cruz Soto et al. (1994) and Chikunya et al. (1996) concluded that on slowly fermented fibrous diets, the growth rate of cellulolytic bacteria is limited more by the slow degradation rate of the energy source than by low availability of peptides and amino acids, when $\mathrm{NH}_{3}$ is in adequate supply. This may explain the lack of response in the EMPS to true protein supplement in our experiment at the low rate of RDP inclusion. Alternatively, it is possible that intraruminal recycling of protein through microbial lysis, which can be substantial with low CP forages (Nolan 1993), may have been sufficient to provide the required protein and/or BCFA precursors for the rumen bacterial population. The measured FOR for rumen fluid and particulate matter on all treatment diets were low $(0.048-0.062 / \mathrm{h}$ for fluid FOR and an average of $0.022 / \mathrm{h}$ for particle FOR), which would have favoured intraruminal recycling of microbial $\mathrm{N}$ in the rumen.

Both in vitro and in vivo experiments have shown clear positive relationships between the EMPS and rumen particle and/or fluid FOR (e.g. Stouthamer and Bettenhaussen 1973; Djouvinov and Todorov 1994). In our experiment, the increased EMPS with the high intake of casein supplement was not associated with a significant increase in rumen fluid or particle FOR, compared with the lower level of casein supplementation, which did not increase the EMPS.

In our experiment, neither the quantity nor the source of RDP had any effect on rate or extent of digestion of the basal diet of pangola grass hay in sacco, or on total NDF digestibility in vivo. It is therefore likely that the increases in OM digestibility and in total DOMI with casein feeding were due to substitution of casein for the less digestible hay portion of the diet, rather than to any effect on rate or extent or digestion of the basal hay diet itself. It is thus evident that the increase in the EMPS with the high intake of RDP supplementation (293 g/kg DOMI) was not associated with corresponding changes in extent or rate of digestion of the basal diet. Our results are in agreement with those of Hunter and Siebert (1985) and Panjaitan et al. (2014) who found that the digestion rates of tropical grass hays did not increase with $\mathrm{N}$ supplementation once $\mathrm{NH}_{3}-\mathrm{N}$ concentrations in the rumen fluid 
were above $50-80 \mathrm{mg} / \mathrm{L}$. Boniface et al. (1986) and Morrison et al. (1988) found that the digestion rate of black speargrass (Heteropogon contortus) hay was not increased by increasing $\mathrm{NH}_{3}-\mathrm{N}$ concentrations above 45 and $25 \mathrm{mg} / \mathrm{L}$, respectively. Additionally, Bowen et al. (2010) reported no association between rumen $\mathrm{NH}_{3}-\mathrm{N}$ concentration and the rate or extent of digestion of a low-quality, black speargrass hay incubated in the rumen of fistulated steers grazing seven different pasture types, despite a range in rumen $\mathrm{NH}_{3}-\mathrm{N}$ concentrations of 17-382 mg/L. Similarly to our experiment, Panjaitan et al. (2014) showed no difference between NPN and true protein supplements in their effect on the rate of digestion of temperate or tropical grass hays.

In our experiment, the lack of any significant effects of treatment on total VFA concentration, rumen fluid $\mathrm{pH}$, rumen fluid volume, rumen digesta DM weight or particle FOR are in accord with the lack of effect on the rate or extent of digestion of the basal hay diet. The mechanisms responsible for the increase in EMPS achieved with very high levels of RDP supplement from true protein are not clear, although they were associated with very high concentrations of rumen $\mathrm{NH}_{3}-\mathrm{N}$ and BCFA. This area requires more research to understand and manipulate the mechanism as the response by the animal to this extra protein would be quite significant.

In conclusion, these experiments have demonstrated that the EMPS in steers consuming low-quality tropical grass hay could only be increased to the higher end of the feeding standards' range when RDP was provided at the very high level of $293 \mathrm{~g} / \mathrm{kg}$ DOMI. However, at intakes of RDP formulated to achieve EMPS in the feeding standards' range (i.e. 130-170 g RDP/ DOMI) there was no difference between NPN and degradable true protein sources to supply $\mathrm{N}$ for microbial protein synthesis.

\section{Acknowledgements}

This study was mainly funded by the Department of Agriculture and Fisheries (DAF), Queensland, who provided post-graduate support for M. K. Bowen. M. K. Bowen was also in receipt of an Australian Government Postgraduate Research Award. We are grateful to the chemists of the former Health and Nutritional Biochemistry Laboratory of DAF and to M. Nielsen of the University of Queensland for conducting laboratory analyses. V. Doogan of DAF assisted with statistical analysis. The skilled technical assistance of J. Kidd and the staff of the former Mt Cotton Research Farm is appreciated. We also thank C. Trevor for providing assistance with field work and analyses as part of her Honour's project.

\section{References}

Agricultural and Food Research Council (AFRC) (1993) 'Energy and protein requirements of ruminants. An advisory manual prepared by the AFRC technical committee on responses to nutrients.' (CAB International: Wallingford, UK)

Amos HE, Evans J (1976) Supplementary protein for low quality bermudagrass diets and microbial protein synthesis. Journal of Animal Science 43, 861-868. doi:10.2527/jas1976.434861x

Balcells J, Parker DS, Guada JA, Piero JM (1992) Simultaneous analysis of allantoin and oxypurines in biological fluids by high-performance liquid chromatography. Journal of Chromatography B: Biomedical Sciences and Applications 575, 153-157. doi:10.1016/0378-4347(92)80517-T

Beever DE, Dhanoa MS, Losada HR, Evans RT, Cammell SB, France J (1986) The effect of forage species and stage of harvest on the processes of digestion occurring in the rumen of cattle. British Journal of Nutrition 56, 439-454. doi:10.1079/BJN19860124

Ben-Ghedalia D, McMeniman NP, Armstrong DG (1978) The effect of partially replacing urea nitrogen with protein $\mathrm{N}$ on $\mathrm{N}$ capture in the rumen of sheep fed a purified diet. British Journal of Nutrition 39, 37-44. doi:10.1079/BJN19780009

Bolleter WT, Bushman CJ, Tidwell PW (1961) Spectrophotometric determination of ammonia as indophenol. Analytical Chemistry 33, 592-594. doi:10.1021/ac60172a034

Boniface AN, Murray RM, Hogan JP (1986) Optimum level of ammonia in the rumen liquor of cattle fed tropical pasture hay. Proceedings of the Australian Society of Animal Production 16, 151-154.

Bowen MK, Poppi DP, McLennan SR, Doogan VJ (2006) A comparison of the excretion rate of endogenous purine derivatives in the urine of Bos indicus and Bos taurus steers. Australian Journal of Agricultural Research 57, 173-177. doi:10.1071/AR05182

Bowen MK, Poppi DP, McLennan SR (2008) Ruminal protein degradability of a range of tropical pastures. Australian Journal of Experimental Agriculture 48, 806-810. doi:10.1071/EA07414

Bowen MK, Poppi DP, McLennan SR (2010) Rumen degradability of a tropical grass hay in cattle grazing different pasture types. Proceedings of the Australian Society of Animal Production 28, 57.

Bowen MK, Poppi DP, McLennan SR (2016) Efficiency of rumen microbial protein synthesis in cattle grazing tropical pasture as estimated by a novel technique. Animal Production Science. doi:10.1071/AN15535

Bryant MP (1973) Nutritional requirements of the predominant rumen cellulolytic bacteria. Federation Proceedings 32, 1809-1813.

Bryant MP, Robinson IM (1962) Some nutritional characteristics of predominant culturable rumen bacteria. Journal of Bacteriology 84, 605-614.

Chen XB, Gomes MJ (1995) 'Estimation of microbial protein supply to sheep and cattle based on urinary excretion of purine derivatives: an overview of the technical details.' (International Feed Resources Unit, Rowett Research Institute: Bucksburn, Aberdeen, UK)

Chikunya S, Newbold CJ, Rode L, Chen XB, Wallace RJ (1996) Influence of dietary rumen-degradable protein on bacterial growth in the rumen of sheep receiving different energy sources. Animal Feed Science and Technology 63, 333-340. doi:10.1016/S0377-8401(96)00999-6

Corbett JL (1987) Energy and protein utilization by grazing animals. In 'Temperate pastures: their production, use and management'. (Eds JL Wheeler, CJ Pearson, GE Robards) pp. 341-355. (CSIRO Publishing: Melbourne)

Corbett JL, Furnival EP, Inskip MW, Pickering FS (1982) Protein digestion in grazing sheep. In 'Forage protein in ruminant animal production'. Occasional Publication No. 6. (Eds DJ Thomson, DE Beever, RG Gunn) pp. 141-143. (British Society of Animal Production: Thames Ditton, UK)

Cruz Soto R, Muhammed SA, Newbold CJ, Stewart CS, Wallace RJ (1994) Influence of peptides, amino acids and urea on microbial activity in the rumen of sheep receiving grass hay and on the growth of rumen bacteria in vitro. Animal Feed Science and Technology 49, 151-161. doi:10.1016/ 0377-8401(94)90088-4

de Vega A, Poppi DP (1997) Extent of digestion and rumen conditions as factors affecting passage of liquid and digesta particles in sheep. The Journal of Agricultural Science 128, 207-215. doi:10.1017/S00218596 96004078

Detmann E, Valente EEL, Batista ED, Huhtanen P (2014) An evaluation of the performance and efficiency of nitrogen utilization in cattle fed tropical grass pastures with supplementation. Livestock Science 162, 141-153. doi:10.1016/j.livsci.2014.01.029

Djouvinov DS, Todorov NA (1994) Influence of dry matter intake and passage rate on microbial protein synthesis in the rumen of sheep and its estimation by cannulation and a non-invasive method. Animal Feed Science and Technology 48, 289-304. doi:10.1016/0377-8401(94)90179-1 
Foss Tecator (2002a) Application sub-note ASN 3805. The determination of neutral detergent fibre using the fibercap system. Foss Tecator, Hoganas, Sweden.

Foss Tecator (2002b) Application sub-note ASN 3804. The determination of acid detergent fibre using the fibercap system. Foss Tecator, Hoganas, Sweden.

Hume ID (1970a) The response of microbial protein in the rumen. II. A response to higher volatile fatty acids. Australian Journal of Agricultural Research 21, 297-304. doi:10.1071/AR9700297

Hume ID (1970b) Synthesis of microbial protein in the rumen. III. The effect of dietary protein. Australian Journal of Agricultural Research 21, 305-314. doi:10.1071/AR9700305

Hunter RA, Siebert BD (1985) Utilization of low-quality roughage by Bos taurus and Bos indicus cattle. 1. Rumen digestion. British Journal of Nutrition 53, 637-648. doi:10.1079/BJN19850073

McDonald I (1981) A revised model for the estimation of protein degradability in the rumen. Journal of Agricultural Science 96, 251-252. doi:10.1017/S0021859600032081

Morrison M, Hogan JP, Murray RM (1988) Evaluation in vitro of ammonia nitrogen requirements for rumen fermentation and protein synthesis with mature tropical forage. Proceedings of the Australian Society of Animal Production 17, 266-269.

Nolan JV (1993) Nitrogen kinetics. In 'Quantitative aspects of ruminant digestion and metabolism'. (Eds JM Forbes, J France) pp. 123-143. (CAB International: Wallingford, UK)

NRDR (2007) 'Nutrient requirements of domesticated ruminants.' (CSIRO Publishing: Melbourne)

Panjaitan T, Quigley SP, McLennan SR, Swain T, Poppi DP (2010) Intake, retention time in the rumen and microbial protein production of Bos indicus steers consuming grasses varying in crude protein content. Animal Production Science 50, 444-448. doi:10.1071/AN09197

Panjaitan T, Quigley SP, McLennan SR, Swain AJ, Poppi DP (2014) Digestion of forages in the rumen is increased by the amount but not type of protein supplement. Animal Production Science 54, 1363-1367.

Panjaitan T, Quigley SP, McLennan SR, Swain AJ, Poppi DP (2015) Spirulina (Spirulina platensis) algae supplementation increases microbial protein production and feed intake and decreases retention time of digesta in the rumen of cattle. Animal Production Science 55, 535-543. doi:10.1071/ AN13146
Poppi DP, McLennan SR (1995) Protein and energy utilization by ruminants at pasture. Journal of Animal Science 73, 278-290. doi:10.2527/1995. $731278 \mathrm{x}$

Poppi DP, McLennan SR (2010) Nutritional research to meet future challenges. Animal Production Science 50, 329-338. doi:10.1071/ AN09230

Poppi DP, McLennan SR, Bediye S, de Vega A, Zorrilla-Rios J (1997) Forage quality: strategies for increasing nutritive value of forages. In 'Proceedings of the XVIII international grassland congress', 8-19 June 1997, Winnipeg, Manitoba, Saskatoon, Saskatchewan, Canada. (Eds JG Buchanan-Smith, LD Bailey, P McCaughey) pp. 307-322. (Association Management Centre of the Canadian Forage Council, Canadian Society of Agronomy and Canadian Society of Animal Science: Calgary, Canada)

Reynolds CK, Kristensen NB (2008) Nitrogen recycling through the gut and the nitrogen economy of ruminants: an asynchronous symbiosis. Journal of Animal Science 86, E293-E305. doi:10.2527/jas.2007-0475

Satter LD, Slyter LL (1974) Effect of ammonia concentration on rumen microbial protein production in vitro. British Journal of Nutrition 32 , 199-208. doi:10.1079/BJN19740073

Stouthamer AH, Bettenhaussen C (1973) Utilization of energy for growth and maintenance in continuous and batch cultures of microorganisms. A reevaluation of the method for the determination of ATP production by measuring molar growth yields. Biochimica et Biophysica Acta 301, 53-70. doi:10.1016/0304-4173(73)90012-8

Sweeney RA (1989) Generic combustion method for determination of crude protein in feeds. Journal - Association of Official Analytical Chemists 72, 770-774.

Tuyen DV, Tolosa XM, Poppi DP, McLennan SR (2015) Effect of varying the proportion of molasses in the diet on intake, digestion and microbial protein production by steers. Animal Production Science 55, 17-26. doi:10.1071/AN13225

Valadares Filho SC, dos Santos Pina D, Chizotti ML, Ferreira Diniz Valaderes R (2010) Ruminal feed protein degradation and microbial protein synthesis. In 'Nutrient requirements of zebu beef cattle BR-Corte'. 2nd edn. (Eds S De Campos Valadares Filho, M Inacio Marcondes, M Chizzotti, P Veiga Rodrigues Paulino) pp. 13-44. (Federal University of Vicosa, Department of Animal Science: Vicosa, Brazil) 